\title{
A new species of Gladioglanis Ferraris \& Mago-Leccia from rio Aripuanã, Amazonas, Brazil (Siluriformes: Heptapteridae)
}

\author{
Marcelo Salles Rocha, Renildo Ribeiro de Oliveira and Lúcia H. Rapp Py-Daniel
}

\begin{abstract}
A new species of Gladioglanis is described from a single locality on rio Aripuanã, rio Madeira basin, and can be distinguished from its congeners by the following characters: dorsal-fin spine and spinelet absent, first dorsal-fin ray flexible, unbranched, followed by five branched dorsal-fin rays, pectoral-fin spine short and with few ( 5 anterior-side, 4 posterior-side) dentations, 22-25 anal-fin rays, round profile of the head in dorsal view, first dorsal-fin pterygiophore in contact with the neural spine of eighth vertebrae, 13 caudal-fin rays in both upper and lower lobes, and 60 total vertebrae. Some of its characters are discussed below and compared among the species of a small clade within Heptapteridae proposed by Bockmann (1998).
\end{abstract}

Uma nova espécie de Gladioglanis é descrita de uma única localidade no rio Aripuanã, bacia do rio Madeira, e pode ser diferenciada de seus congêneres pelos seguintes caracteres: espinho dorsal e trava do espinho ausentes, primeiro raio da dorsal simples, flexível, seguido de cinco raios ramificados na nadadeira dorsal, espinho peitoral menor e com poucas (5 anteriores e 4 posteriores) serras, 22-25 raios na nadadeira anal, perfil da cabeça arredondado em vista dorsal, primeiro pterigióforo da nadadeira dorsal em contato com o espinho neural da oitava vértebra, 13 raios na nadadeira caudal em ambos lobos superior e inferior, e 60 vértebras. Alguns dos caracteres são discutidos e comparados entre as espécies de um pequeno clado dentro de Heptapteridae proposto por Bockmann (1998).

Key words: Catfish, Taxonomy, Gladioglanis conquistador, Gladioglanis machadoi.

\section{Introduction}

The heptapterid catfish genus Gladioglanis was proposed by Ferraris \& Mago-Leccia (1989) based on the unique (among heptapterids) character of unossified lateral-line canal ossifications, plus a combination of derived features. Lundberg et al. (1991) expanded the diagnosis of Gladioglanis to include seven synapomorphies that corroborate its monophyly: all cephalic sensory canals contained in wide bony tubes roofed by extremely thin sheets of bone, vomer reduced or absent, low number of pectoral-fin rays, ornate pectoral spines, elongate coracoid keel, short but stout dorsal-fin spine, and dorsal-ventral asymmetry of caudal-fin ray numbers.

Bockmann (1998) proposed a well-corroborated clade within the Heptapteridae, composed of Gladioglanis, Phreatobius and genera with highly developed jaw adductor muscles (Brachyglanis, Leptorhamdia and Myoglanis). Also, Bockmann (1998) presented phylogenetic evidence for a sister group relationship between Gladioglanis and Phreatobius within this clade.
Presently, Gladioglanis comprises two valid species, its type species G. machadoi Ferraris \& Mago-Leccia (1989), from Venezuela, and G. conquistador Lundberg, Bornbusch \& Mago-Leccia (1991), from Ecuador (Bockmann \& Guazzelli, 2003). Gladioglanis occur in small, shallow, clear or blackwater streams on substrates of leaf litter and on accumulated detritus (Ferraris \& Mago-Leccia, 1989; Lundberg et al., 1991) and their diet includes small invertebrates (Ferraris \& MagoLeccia, 1989).

Recently, field work on rio Aripuanã, rio Madeira basin (PROBIO project), Amazonas state, Brazil, yielded two specimens of a new and distinct species of Heptapteridae, which is described herein.

\section{Material and Methods}

Measurements were made to the nearest $0.1 \mathrm{~mm}$ using a digital caliper with the aid of a stereomicroscope. Measurements are given as percentages of standard length (SL) or head length (HL). Landmarks for measurements and measure-

Coleção de Peixes, Instituto Nacional de Pesquisas da Amazônia, Caixa Postal 478, 69011-970 Manaus, AM, Brazil. rochainpa@yahoo.com.br; deoliveirarr@hotmail.com; rapp@inpa.gov.br 


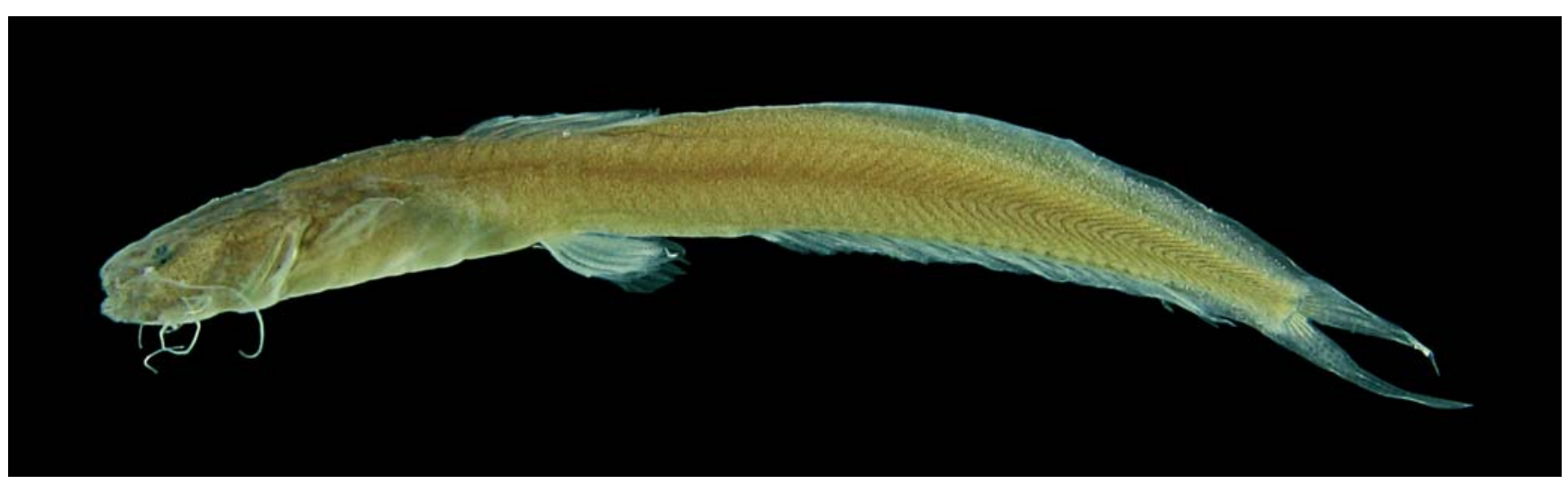

Fig. 1. Gladioglanis anacanthus, holotype, INPA 28446, 26.3 mm SL, Brazil, Amazonas, Novo Aripuanã, rio Aripuanã, lake inside Mamão Island. Photograph by R. R. de Oliveira.

ment terminology follow Lundberg \& McDade (1986) and Lundberg et al. (1991). All fin elements are included in fin-ray counts. For the caudal fin we report the total count in each lobe. Pleural ribs, all fin rays and vertebral counts were obtained from a single cleared and stained (cs) specimen prepared following Taylor \& Van Dyke (1985). Institutional abbreviations follow the Catalog of Fishes website at http:// www.calacademy.org/research/ichthyology/catalog/ abtabr.html.

\section{Results}

\section{Gladioglanis anacanthus, new species} Fig. 1-2

Holotype. INPA 28446 (26.3 mm SL), Brazil, Amazonas, Novo Aripuanã, rio Aripuanã, lake on Mamão Island, $06^{\circ} 08^{\prime} 48^{\prime \prime} S$ 60¹1'50”'W, 29 Apr 2005, L. Rapp Py-Daniel et al.

Paratype. INPA 28447 (21.5 mm SL, cs), same data as holotype.

Diagnosis. Gladioglanis anacanthus n. sp. can be distinguished from its congeners by the following features: dorsalfin spine and spinelet absent ( $v s$. both structures present); first dorsal-fin ray (homologous to spine) flexible, unbranched, followed by five branched dorsal-fin rays ( $v s$. spinelet, spine and six branched dorsal-fin rays in congeneric species); pectoral-fin spine 5.8-6.1\% of SL (vs. 9.2\% in G. conquistador and $8.2 \%$ in G. machadoi); dentations on pectoral spine 5 on anterior side and 4 on posterior (vs. 5-8 on anterior and 6-8 on posterior side in G. conquistador, and 10 on anterior and 7 on posterior in G. machadoi); anal-fin rays 22-25 (vs. 15-21 in G. conquistador and 15-19 in G. machadoi); round profile of the head in dorsal view ( $v s$. triangular shaped in dorsal view in congeners); first pterygiophore of dorsal fin in contact with neural spine of eighth vertebra (vs. seventh vertebra in $G$. conquistador and sixth vertebra in G. machadoi); both caudal-fin lobes with 13 rays, (vs. upper and lower lobes with 1318 and 9-13 rays respectively in G. conquistador and 20-24 and 12-15 in G. machadoi), 60 total vertebrae (vs. 48-51 in G. conquistador and 45-48 in G. machadoi)

Description. Morphometric data is presented in Table 1. Body slender and elongate. Head depressed; dorsal profile of head rounded. Body compressed from pectoral-fin origin to caudal peduncle. Skin of head thin and semi-transparent, open cranial fontanels externally visible. Mouth terminal, lower jaw projecting. Premaxillary and dentary tooth small, villiform, in bands.

Barbels ovoid in transversal section. Maxillary barbel inserted above upper lip, posterolateral to anterior nostril and anterior to pore of infraorbital sensory canal; reaching origin of pectoral fin but not exceeding tip of adpressed pectoral fin. Inner mental barbel reaching to or just beyond margin of branchiostegal membrane. Outer mental barbel reaching to or just beyond pectoral-fin insertion. Branchiostegal membranes free and overlapping.

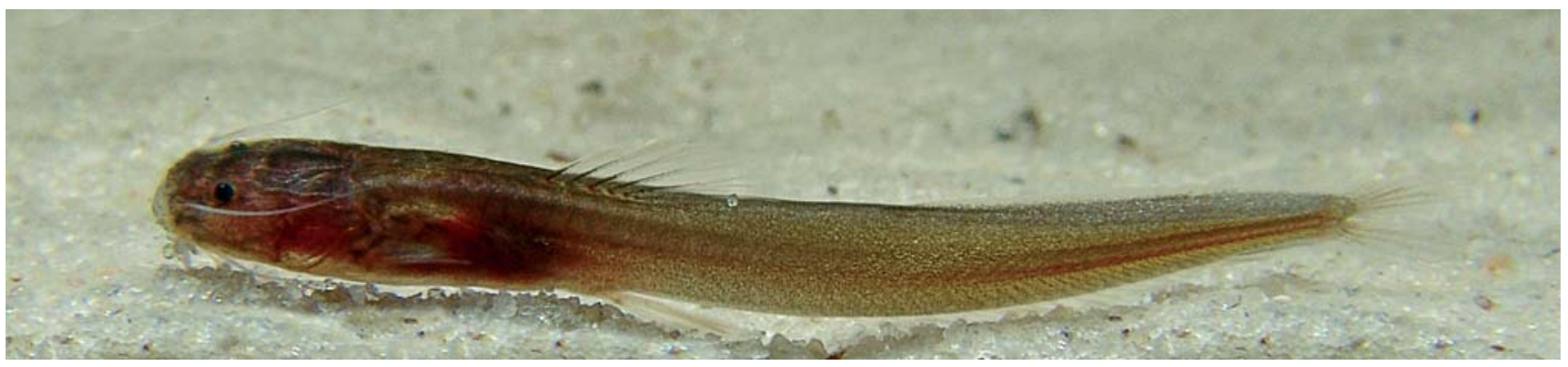

Fig. 2. Gladioglanis anacanthus, holotype, INPA 28446, $26.3 \mathrm{~mm} \mathrm{SL}$, live specimen. Photograph by L. M. de Sousa. 
Table 1. Morphometric data of Gladioglanis anacanthus.

\begin{tabular}{lcc}
\hline Measurement & Holotype & Paratype \\
\hline Standard length (mm) & 26.3 & 21.5 \\
& Percents of standard length & \\
Predorsal length & 31.1 & 33.8 \\
Preanal fin length & 52.3 & 52.3 \\
Head length (fleshy) & 19.1 & 21.2 \\
Head length (bony) & 18.1 & 19.9 \\
Caudal-peduncle length & 10.7 & 10.0 \\
Caudal-peduncle depth & 4.0 & 4.0 \\
Lower caudal-fin lobe & 17.3 & 20.3 \\
Upper caudal-fin lobe & 12.8 & 15.3 \\
Anal-fin base & 35.4 & 37.3 \\
Dorsal fin to adipose fin & 18.3 & 18.7 \\
Body depth & 10.3 & 8.8 \\
Head depth & 8.4 & 8.9 \\
Body width & 13.3 & 14.8 \\
Pectoral-fin spine length & 5.8 & 6.1 \\
Posterior cleithral process & 2.9 & 2.4 \\
Urogenital papilla to anal fin & 14.4 & 10.0 \\
& Percents of head length & \\
Interocular & 25.6 & 24.3 \\
Snout length & 33.2 & 27.3 \\
Internarial length & 14.1 & 9.1 \\
Internarial width & 23.3 & 20.8 \\
Eye (corneal) diameter & 5.0 & 11.0 \\
Eye ball diameter & 8.6 & 4.7 \\
\hline
\end{tabular}

Anterior nostril tubular, located above margin of upper lip; nostril immediately lateral to anterior supraorbital pore and anteromedial to anterior infraorbital pore. Posterior nostril circular and lacking raised rim, located closer to eye than to anterior nostril. Eye small and without free orbital rim; centered on anterior third of head. Sensory canals of head with simple (non-dendritic) tubes leading to large pores.

Dorsal fin without spine and spinelet; six soft fin rays, first ray (homologous to spine) unbranched and articulating with second pterygiophore; five branched rays. First and second pterygiophores inserted between neural spines of vertebrae 8 and 9. Bifid neural spines of vertebra 6 surrounding small, horizontally elongate bone, interpreted as a supraneural. Adipose fin elongate, united to caudal fin; its origin posterior of vertical through origin of anal fin. Anal fin elongate, bearing 22-25 rays. Caudal fin deeply lobed with lower lobe longer; 13 rays in upper lobe and 13 in lower. Pectoral fin with heavy and sharp spine and four slender soft rays. Spine covered with thick layer of skin. Spine with 5 large and sharp dentations on anterior side and 4 on posterior. Posterior cleithral process slender and sharp. Pelvic fin with six rays, first simple, five branched; not reaching anal-fin origin. Urogenital papilla in a depression. Six pleural ribs. Total vertebrae 60 .

Color in alcohol. Body color brownish. Small dark chromatophores scattered over dorsal surfaces of head and body, imparting to body a darker pigmentation. Chromatophores smaller than nares. Ventral portion of body less pigmented. All fins hyaline.

Distribution. Gladioglanis anacanthus was found only at the type locality, lago do Mamão, rio Aripuanã basin, Amazonas state, Brazil (Fig. 3).

Ecological notes. The type locality of $G$. anacanthus is a large lake, lago do Mamão, inside an island (Ilha do Mamão), located in the middle portion of rio Aripuanã (Fig. 3). The new species was first collected during field work on rio Madeira basin (PROBIO project). It was collected together with many specimens of G. conquistador during high water season. The specimens were collected in the flooded forest (igapó) on the border of the lake, in a shallow (up to $0.5 \mathrm{~m}$ ) marginal area on a deep mat of leaf litter as substrate.

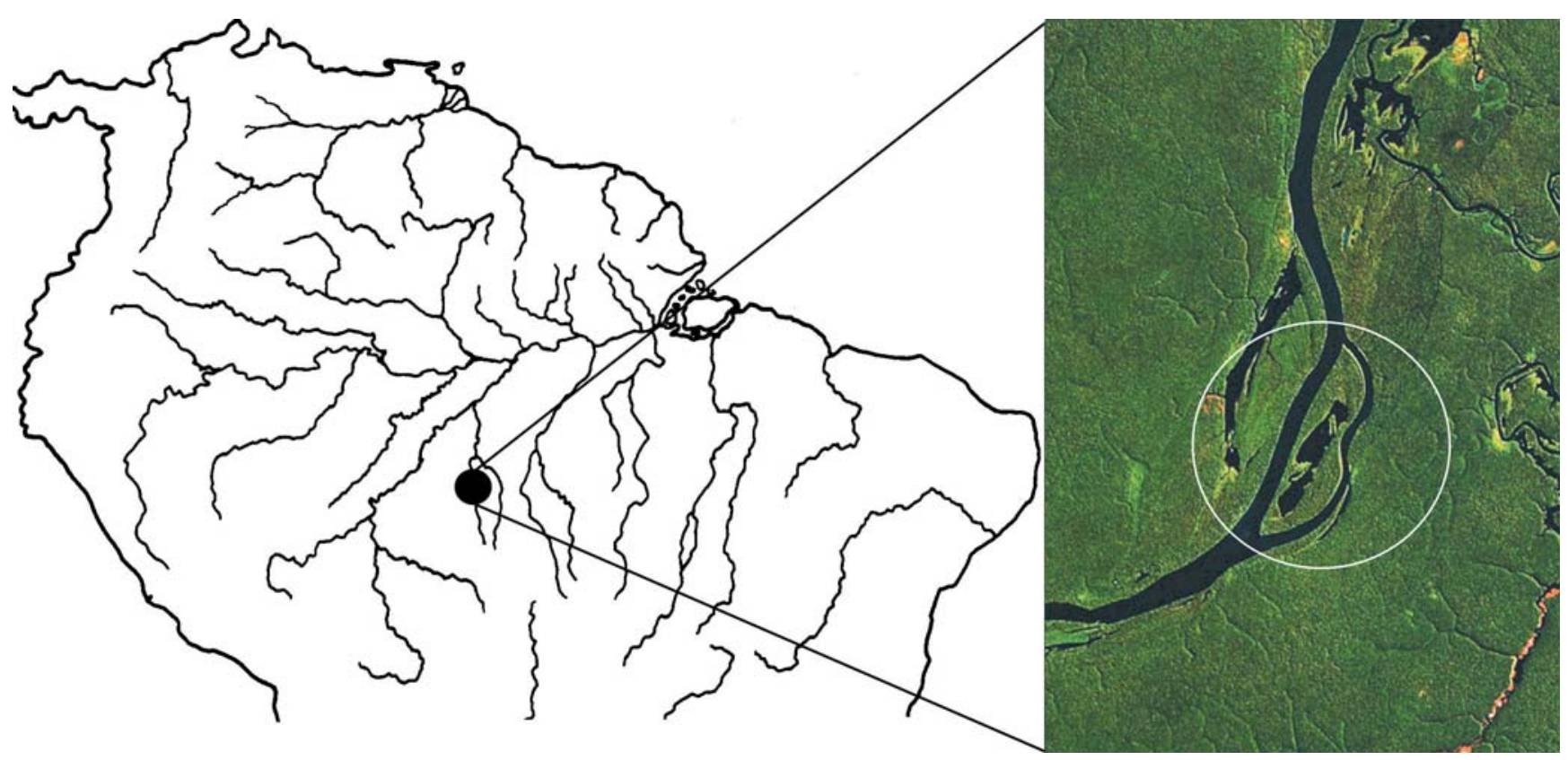

Fig. 3. Partial map of South America showing the type locality of Gladioglanis anacanthus. White circle showing the Mamão lake inside the Mamão Island, in the middle part of rio Aripuanã. 
A second field trip sponsored by the "All Catfish Species Inventory" Project was conducted during the dry season and, as the water receded, the area around the lake was not flooded. The collection was conducted on leaf litter along the shore of the lake. We found more specimens of $G$. conquistador but no additional specimens of the new species.

Etymology. The specific name anacanthus is derived from the Latin an (absence) and canthus (spine) in allusion to the absence of its dorsal-fin spine.

\section{Discussion}

Lundberg et al. (1991) corroborated the monophyly of Gladioglanis on the basis of seven synapomorphies. Among those, only one - a short, stout dorsal-fin spine - shows a different condition in G. anacanthus. The absence of a dorsal-fin spine is considered an apomorphic trait among Siluriformes and, within a restricted clade of the Heptapteridae proposed by Bockmann (1998) (composed by Gladioglanis, Phreatobius, Brachyglanis, Leptorhamdia, and Myoglanis), the absence of this structure was found only in Phreatobius (Bockmann, 1998; pers. obs.). Thus, we herein report the second record of this state for the clade and make some comparisons and comments about $G$. anacanthus within this clade.

In Myoglanis, the ossified portion of the dorsal-fin spine (second lepidotrichia) is very reduced and limited to the basal portion of the ray, under the skin, being externally soft and segmented. In some species, the hemi-rays are fused on the base with a cuneiform shape (V. Masson, pers. comm.). In Gladioglanis anacanthus the first lepidotrichia (spinelet) is absent and the first visible dorsal-fin ray (second lepidotrichia) is not ossified basally, but formed by the two hemi-rays which is well separated and not fused, thus the species is not considered to possess a dorsal-fin spine (Fig. 4).

Lundberg et al. (1991) stated that a short but stout dorsal-fin spine, as seen in Gladioglanis conquistador and $G$. machadoi (Fig. 5), was a derived feature, with the

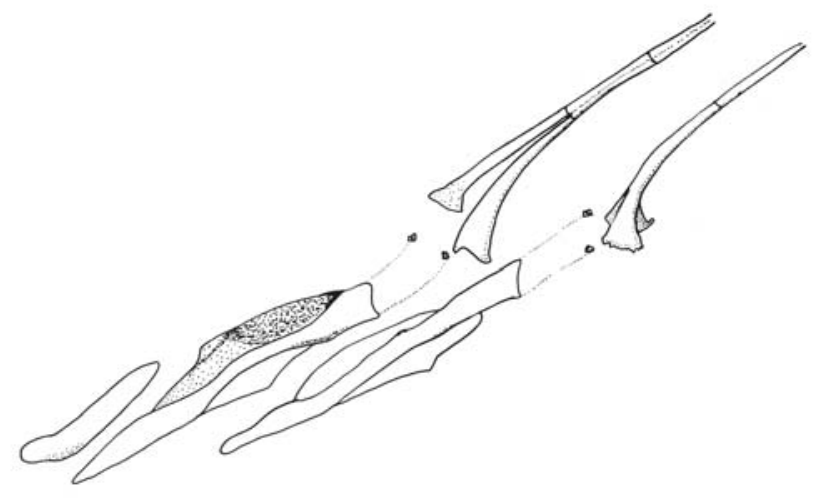

Fig. 4. Gladioglanis anacanthus, paratype, INPA 28447, 21.5 $\mathrm{mm}$ SL. First three dorsal-fin pterygiophores and the first and second dorsal-fin rays. Lateral view, anterior toward left. plesiomorphic condition a well ossified long dorsal-fin spine, as seen in the Pimelodidae, Diplomystidae and in the most basal genera of Heptapteridae such as Goeldiella, Rhamdia and Pimelodella.

Thus, within the clade some states can be recognized for the dorsal-fin spine ossification: a short and stout ossified spine (Gladioglanis machadoi and G. conquistador), a long ossified spine (Leptorhamdia essequibensis, Brachyglanis melas and B. phalacra), spine ossification reduced and restricted under the skin (Myoglanis) and spine unossified or spine absent (Gladioglanis anacanthus and Phreatobius). Bockmann (1998) described two conditions for the dorsal-fin spine, one in which the ossified portion could be cylindrical (plesiomorphic) or alternatively depressed antero-posteriorly (apomorphic).

The presence of a spinelet or first lepidotrichia among Siluriformes is a plesiomorphic condition (Arratia, 2003). Examination of the cleared and stained specimen of Gladioglanis anacanthus revealed that this species does not have the spinelet hidden under the skin, as in Myoglanis species. Within the clade proposed by Bockmann (1998), Leptorhamdia essequibensis, Brachyglanis melas, B. frenata, B. phalacra, Gladioglanis conquistador, and G. machadoi show the plesiomorphic condition and have a well developed spinelet.

The pectoral spine in Gladioglanis (Fig. 5) is the largest within the clade, while Myoglanis and Leptorhamdia show a more reduced pectoral spine. However, within Gladioglanis, G. anacanthus has the shortest pectoral spine, with its dentations covering almost the entire length of the spine (Fig. 6a). This condition is similar to that found in Brachyglanis melas, B. phalacra (Fig. 6d), B. frenata and G. machadoi (Figs. 5, 6c) while in G. conquistador (Fig. 6b), Myoglanis (Fig. 6e) and Leptorhamdia essequibensis (Fig. 6f) the dentations do not extend to the tip of the spine. Phreatobius does not possess a pectoral spine.

The point of contact between the first pterygiophore of dorsal fin and the vertebral column is a diagnostic feature among the Gladioglanis species, as stated by Lundberg et al. (1991). The first pterygiophore is in contact with the seventh vertebra in $G$. conquistador and in the sixth in $G$. machadoi. In G. anacanthus, the first pterygiophore is in contact with the eighth vertebra, however, more specimens are necessary to delimit the range of variation of this character.

Gladioglanis anacanthus shares with Phreatobius some derived characters states, such as the absence of spinelet and dorsal-fin spine. This would suggest a sister relationship between Gladioglanis anacanthus and Phreatobius. Nevertheless, the generic allocation of Gladioglanis anacanthus seems well-corroborated, based on the presence of the synapomorphies proposed by Lundberg et al. (1991). However, these shared features between $G$. anacanthus and Phreatobius, and the hypothesized close relationship between Gladioglanis and Phreatobius (Bockmann, 1998), ren- 


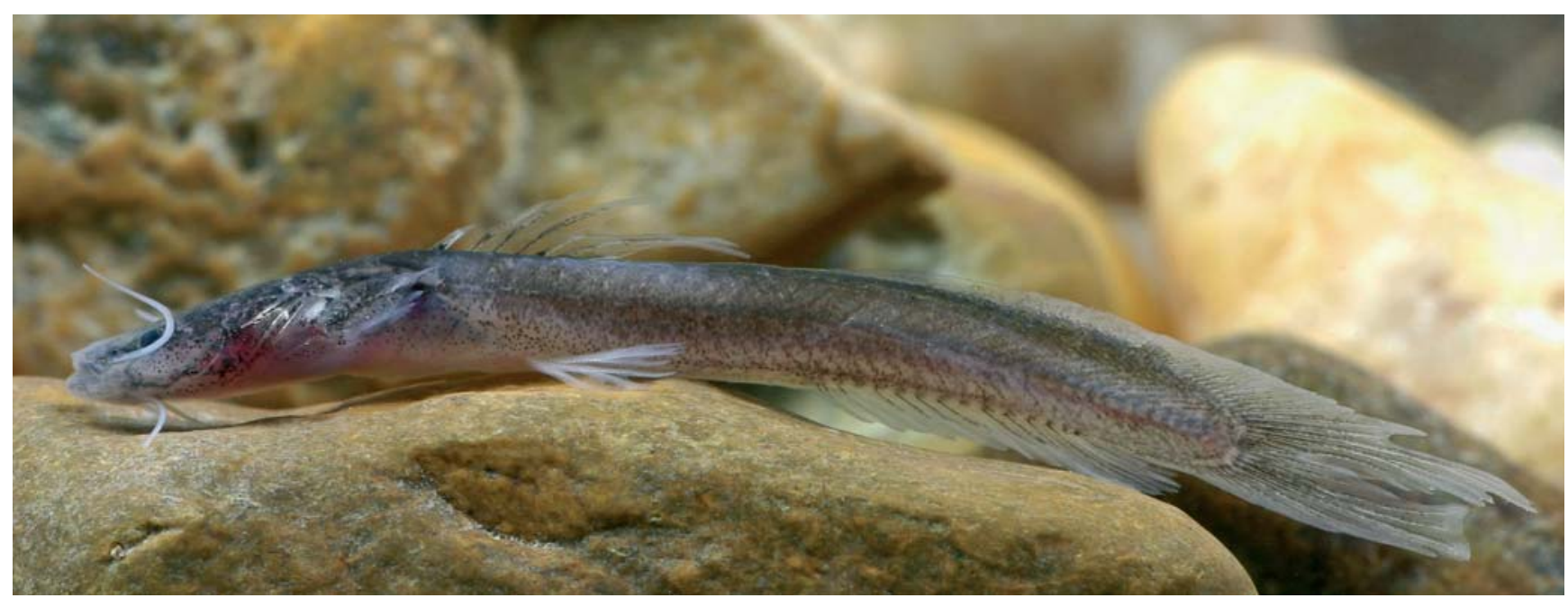

Fig. 5. Gladioglanis machadoi, INPA 29008, 23.1 mm SL, live specimen. Photograph by V. L. Masson.

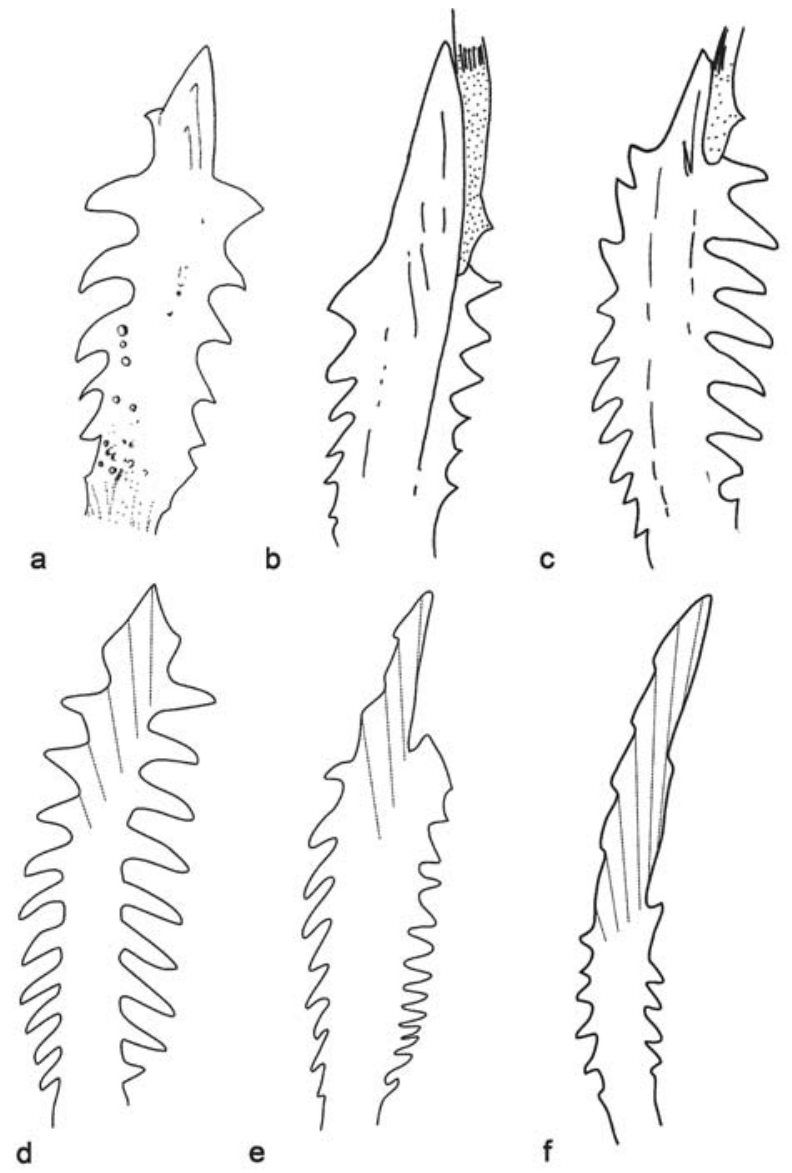

Fig. 6. Pectoral spines in dorsal view of Gladioglanis species and closely related genera. a: Gladioglanis anacanthus, paratype, INPA28447 (21.5mm SL); b: G. conquistador (30 mm SL); c: G. machadoi (27 mm SL); d: Brachyglanis phalacra, holotype, FMNH 53216 (63.2 mm SL); e: Myoglanis sp., MZUSP 37602 (77.8 mm SL); f: Leptorhamdia essequibensis, INPA 10764 (76.9 mm SL). Illustration of G. machadoi and G. conquistador from Lundberg et al. (1991). der G. anacanthus important to understanding the relationships of the species within the clade and to corroborate the position of Phreatobius within Heptapteridae.

Material examined. INPA 25482 Myoglanis koepckei (3 cs, 33.6$52.5 \mathrm{~mm}$ SL), Amazonas, Manaus, rio Cuieiras, igarapé da Reserva Dimona (PDBFF), $80 \mathrm{~km}$ north of Manaus. INPA 11840 Brachyglanis frenata (2 cs, 27.2-28 mm SL), Amazonas, Itacoatiara, rio Urubu, Iracema falls. INPA 26523 Phreatobius sp. (2 cs, 24.2$35.1 \mathrm{~mm}$ SL), Roraima. INPA 27213 Gladioglanis conquistador (16, 20.9-30.7 mm SL), Amazonas, Coari, rio Solimões, igarapé do Mundo, tributary at left bank of igarapé Ipixuna. INPA 27238 Gladioglanis conquistador (3 cs, 28.3-29 mm SL), Amazonas, Coari, rio Solimões, igarapé Munduca, tributary at left bank of igarapé Ipixuna. INPA 28963 Gladioglanis machadoi (4, 23.8-30.1 mm SL), Amazonas, Santa Isabel do Rio Negro, rio Negro, igarapé near São João. INPA 29008 Gladioglanis machadoi (1, $23.1 \mathrm{~mm} \mathrm{SL),}$ Amazonas, Santa Isabel do Rio Negro, rio Negro, igarapé Branco, small tributary at left bank of rio Daraá.

\section{Acknowledgments}

We gratefully acknowledge Vitor Masson (FFCLRP-USP), John Lundberg (ANSP), Flávio Bockmann (FFCLRP-USP), Oscar Shibatta (UEL) and Jansen Zuanon (INPA) for providing information and stimulating discussion on Heptapteridae; Vitor Masson kindly revised the manuscript; prepared illustrations of the pectoral spines of some heptapterids and photographed the live specimen of G. machadoi; Leandro Sousa (MZUSP) photographed the live specimen of G. anacanthus; Daniel Pimpão (INPA) for helping in field trip; André Canto (INPA) for helping and supporting with INPA fish collection procedures; Sr. Gentil provided invaluable help during the expedition to rio Aripuanã, as a guide and driver. MSR and RRO benefited from a CNPq/DTI scholarship, as part of the institutional research program (PCI) at INPA. "All Catfish Species Inventory" Project (NSF DEB 0315963) funded the 2007 expedition and the visit of MSR to ANSP fish collection. 
The first expedition to rio Aripuanã was funded by MMA/ $\mathrm{MCT} / \mathrm{CNPq}$ Brazilian Governament and World Bank as part of the PROBIO project.

\section{Literature Cited}

Arratia, G. 2003. The siluriform postcranial skeleton. An overview. Pp. 121-157. In: Arratia G., B. G. Kapoor, M. Chardon, R. Diogo (Eds.). Catfishes (volume 1). Enfield, Science Publishers, $478 \mathrm{p}$.

Bockmann, F. A. 1998. Análise filogenética da família Heptapteridae (Teleostei, Ostariophysi, Siluriformes) e redefinição de seus gêneros. Unpublished Ph.D. Dissertation, Universidade de São Paulo, São Paulo. 599p.

Bockmann, F. A. \& G. M. Guazzelli. 2003. Family Heptapteridae (Heptapterids), Pp. 406-431. In: Reis, R. E., S. O. Kullander \& C. J. Ferraris, Jr. (Eds.). Checklist of the freshwater fishes of South and Central America. Porto Alegre, Edipucrs, 729p.
Ferraris, Jr., C. J. \& F. Mago-Leccia. 1989. A new genus and species of pimelodid catfish from the Río Negro and Río Orinoco drainages of Venezuela (Siluriformes: Pimelodidae). Copeia, 1989(1): 166-171.

Lundberg, J. G. \& L. A. McDade. 1986. On the South American catfish Brachyrhamdia imitator Myers (Siluriformes, Pimelodidae), with phylogenetic evidence for a large intrafamilial lineage. Notulae Naturae, Academy of Natural Sciences of Philadelphia, 463: 1-24.

Lundberg, J. G., A. H. Bornbusch \& F. Mago-Leccia. 1991. Gladioglanis conquistador n. sp., from Ecuador with diagnoses of the subfamilies Rhamdiinae Bleeker and Pseudopimelodinae n. subf. (Siluriformes, Pimelodidae). Copeia, 1991(1): 190-209.

Taylor, W. R. \& G. C. Van Dyke. 1985. Revised procedures for staining and clearing small fishes and other vertebrates for bone and cartilage study. Cybium 9: 107-119.

Accepted August, 2008

Published September 30, 2008 